\title{
INFLUENCE OF SPACE-TIME HETEROGENEITY OF WATER CONSUMPTION CONDITIONS ON THE PARAMETERS OF A WATER SUPPLY SYSTEM
}

\author{
Ewa OGIOŁDA ${ }^{1}$, Ireneusz NOWOGOŃSKI ${ }^{1}$, Maciej BABIUCH ${ }^{2}$ \\ ${ }^{1}$ University of Zielona Góra, Zielona Góra, Poland \\ ${ }^{2}$ Graduated of Environmental Engineering
}

\begin{abstract}
The work presents the results of the analysis of an existing water supply system. It contains a description of the analysed area in which the analysed system was located, as well as its parameters regarding water intakes and transport of water with pumps, the length and diameter of pipes, and a complication of the materials used to construct the network. Water demand accounting for the nature of the consumers using the water supply network was subject to analysis. The influence of changes in the distribution of water within a day for the basic categories of recipients was accounted for. The EPANET 2.0 program for the simulating water supply network operation, made available by the U.S. Environmental Protection Agency through a public-domain licence, was used to construct the model of the system. The obtained results of the simulation allowed for indicating the main problems with the use of the analysed system. Subject to analysis was the pressure pattern in characteristic nodes of the network from which mining companies, industrial plants and residential households were supplied. Usefulness of the developed simulation model in preparing the assessment of future modernization works was confirmed, allowing for the effects of their implementation to be assessed.
\end{abstract}

Keywords: irregularity of water consumption, hydraulic parameters of water supply network

\footnotetext{
${ }^{1}$ Corresponding author: University of Zielona Góra, Faculty of Civil Engineering, Architecture and Environmental Engineering, Institute of Environmental Engineering, Szafrana st 15, 65-246 Zielona Góra, e-mail: e.ogiolda@iis.uz.zgora.pl
} 


\section{INTRODUCTION}

Water supply systems supply various recipients - cities, villages, industrial plants. The requirements of individual consumers can vary significantly in terms of size and the irregularity of use and quality, or water pressure. In municipal settlement units, water can be intended for the needs of residents, service industries, fire safety objectives and others connected with the running of cities. The percentage shares of water demand within a day characteristic of individual elements of spatial development have been presented in the Guidelines [6]. In rural areas, water consumption connected with crop and animal production should be additionally accounted for $[3,4]$. Recipients with specific requirements are industrial plants, whose balance accounts for both the water required for the personal needs of staff, as well as water demand for production purposes, and the irregularity of which is connected with the cycle of work shifts [1] and the specificity of the production technology.

The irregularity of water consumption has an influence on the performance parameters characterizing specific systems. Therefore, a water supply system supplying both residents as well as industrial plants of a varied nature was subject to analysis.

\section{DESCRIPTION OF WATER SUPPLY SYSTEM}

The analyzed system is located in the area of three communes in the Dolnośląskie Province: Rudna, Polkowice and Lublin. It is supplied by 3 independent water intakes, which comprise a total of 11 deep water wells equipped with deep-well pumps manufactured by Grundfos. Such a solution allows for ensuring a constant supply of water to the consumers.

Built in the 60s of the XX century, the water system network is very extensive. It is supplied by three water pumping rooms, in which Grundfos pressure boosting systems were applied. A characteristic trait of these is the wide diversity of applied pipeline materials. The percentage shares of pipelines of a given diameter and made from given materials have been presented in Figs. 1 and 2. The total length of the pipelines is approximately $43.35 \mathrm{~m}$.

The natural topography of the land is that of a flatland - the elevation ranges from 144.8 to 160.00 meters above sea level. An exception to this is the area of one water intake, the area of which lies at elevation ranging from 166.50 to 193.50 meters above sea level. The diversity of the terrain elevations in the area supplying the water system has been presented in Fig. 3 . 


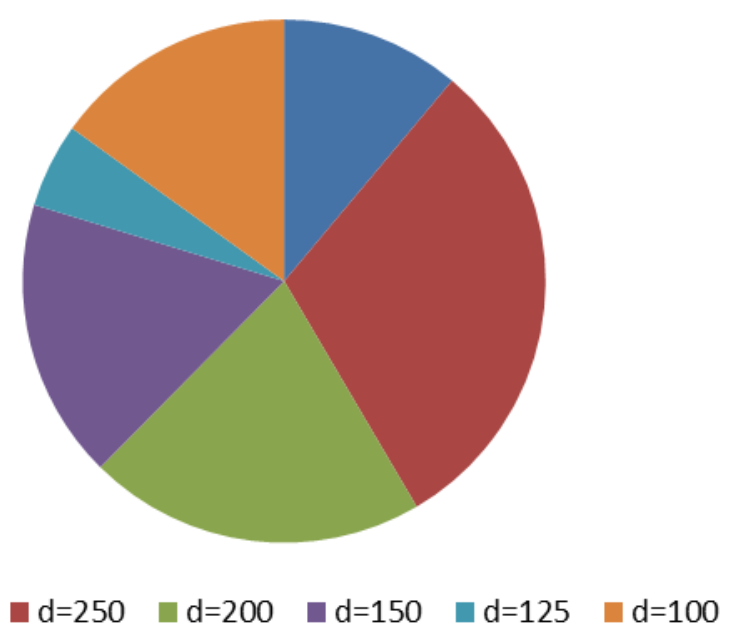

Fig. 1. Percentage share of pipelines of a given diameter in the water supply system

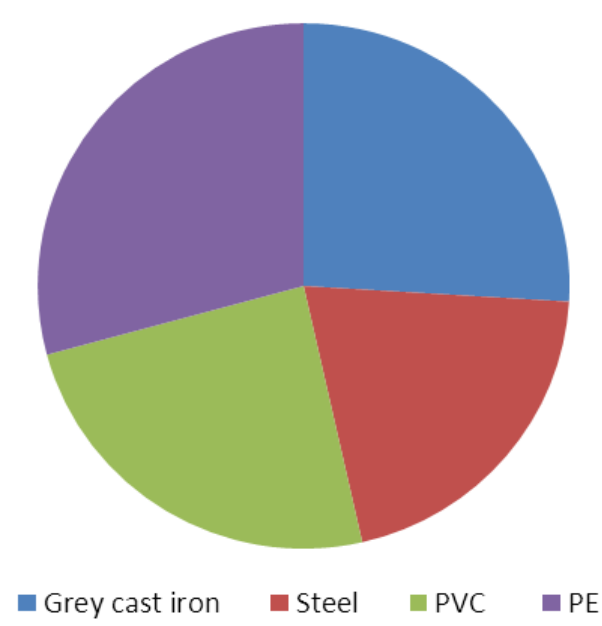

Fig. 2. Percentage share of pipelines made of a given material in the water supply system 


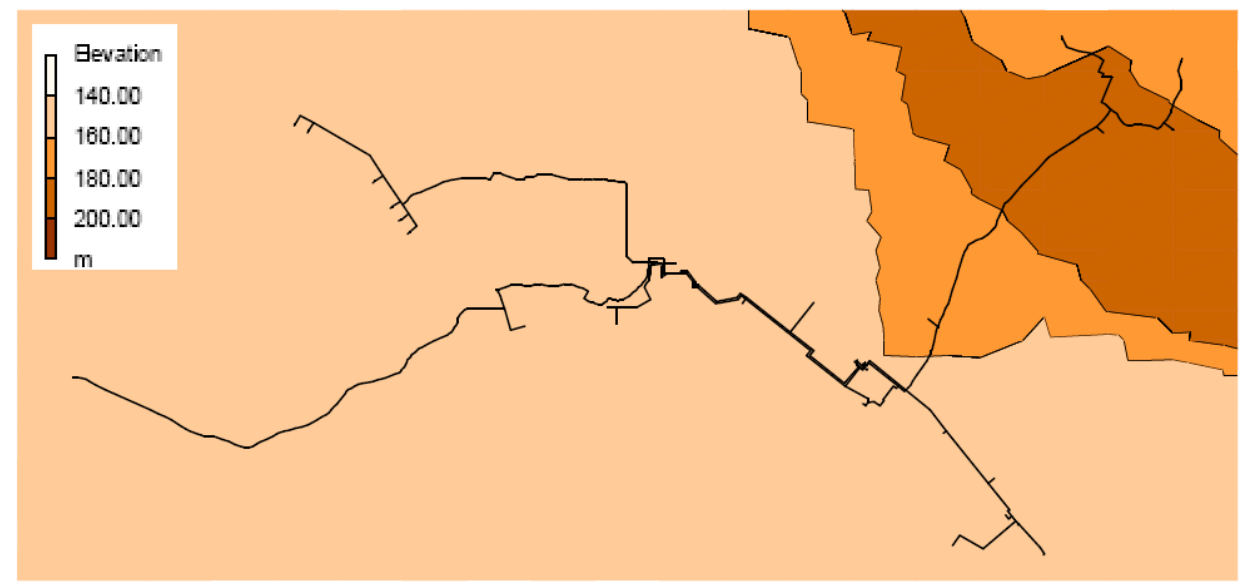

Fig. 3. Contour lines of the elevations in the area of the intake

The analysed system supplies water to a series of consumers of a diverse nature. The main recipients are mining companies in the region of Lubin, which require uninterrupted supply. Industrial/commercial businesses, where water is designated for production as well as for utility purposes, are also supplied. Also connected to the system are residential households in four villages. The values of water consumption have been established on the basis of monthly water meter readings.

\section{HYDRAULIC CALCULATIONS FOR THE WATER SUPPLY SYSTEM}

\subsection{Calculation methodology}

A model of the system prepared using the Epanet program, prepared and made available by the United States Environmental Protection Agency, served as the basis for calculations. The program allows for carrying out calculations regarding the hydraulic parameters and characterizing water quality. It can be applied for the analysis of existing networks, as well as for calculations simulating planned or modernized systems [5]. The input data are:

- a graph of the network (accounting for pumping stations and water tanks, usually covering the pipeline system within a pumping station and tank fittings),

- for nodes: pipeline axis ordinate, volume and irregularity of water demand,

- for pipelines: length, diameter, roughness, local loss coefficient,

- pump characteristics,

- tank parameters. 
With the Epanet program, pressure loss calculations can be carried out using one of the following formulas [5]: Darcy-Weisbach, Chezy-Manning and HazenWilliams. Under Polish conditions, the Darcy-Weisbach method is usually applied to analyse water supply networks, and was thus chosen for further calculations [2]:

$$
\Delta h_{l}=\lambda \frac{v^{2}}{2 g} \cdot \frac{l}{d}
$$

where:

$\Delta \mathrm{h}_{1}$ - pressure loss over length of pipe, $\mathrm{m}$;

$\lambda$ - linear friction coefficient;

$\mathrm{v}$ - average water flow velocity, $\mathrm{m} \cdot \mathrm{s}^{-1}$;

$\mathrm{g}$ - gravitational acceleration, $\mathrm{m} \cdot \mathrm{s}^{-2}$;

1 - length of pipe, $\mathrm{m}$;

$\mathrm{d}$ - inner diameter of pipeline, $\mathrm{m}$.

The developed model comprises 72 nodes and 74 stretches. The network is characterized by a mixed system. A graph of the water supply system has been presented in Fig. 4.

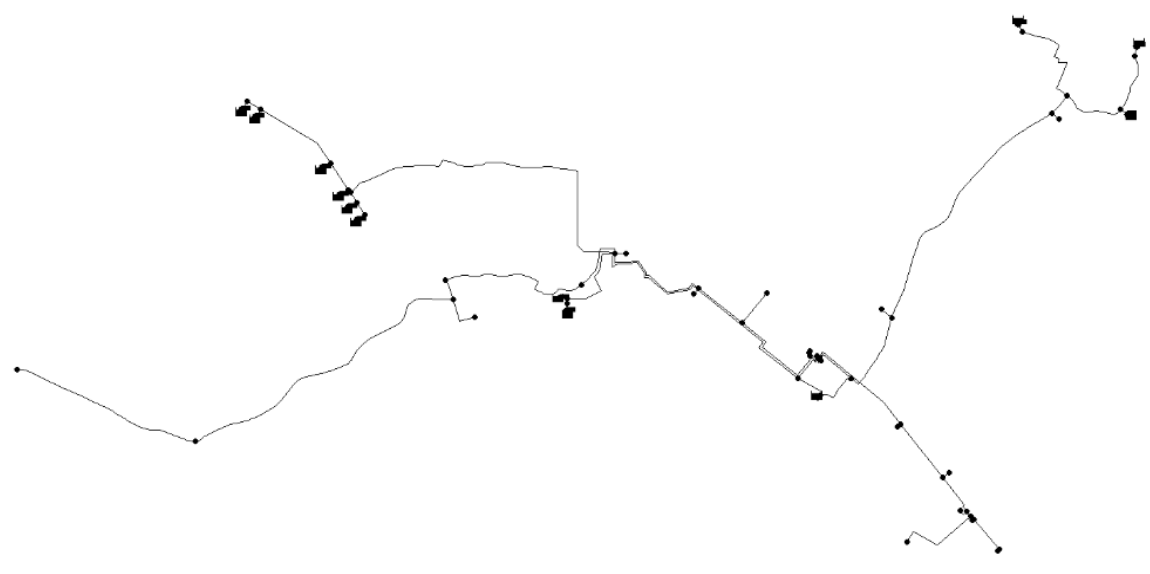

Fig. 4. Graph of water supply network

Hourly water consumption for the individual consumers was accounted for in the calculations, the course of which has been presented in Fig. 5. 


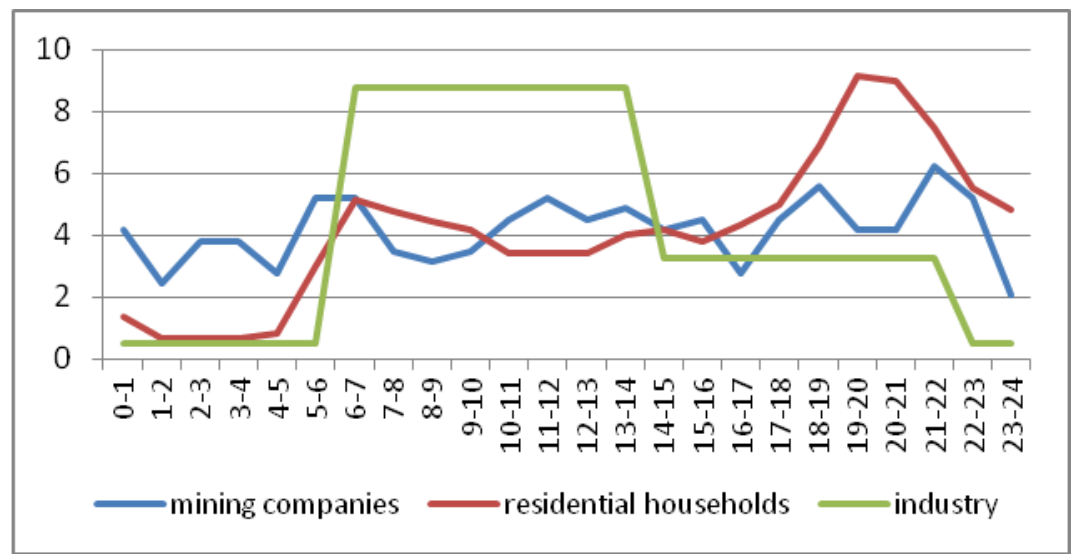

Fig. 5. Hourly water consumption of individual consumers

\subsection{Results of Calculations}

Calculations of hydraulic parameters of the water supply network were carried out using the Epanet program. The main consumers are mining companies, with lower parameters revealed for industrial plants and the lowest water consumption for residential households. Figure 6 shows the pattern of changes in the total flow rate during individual hours of the day.

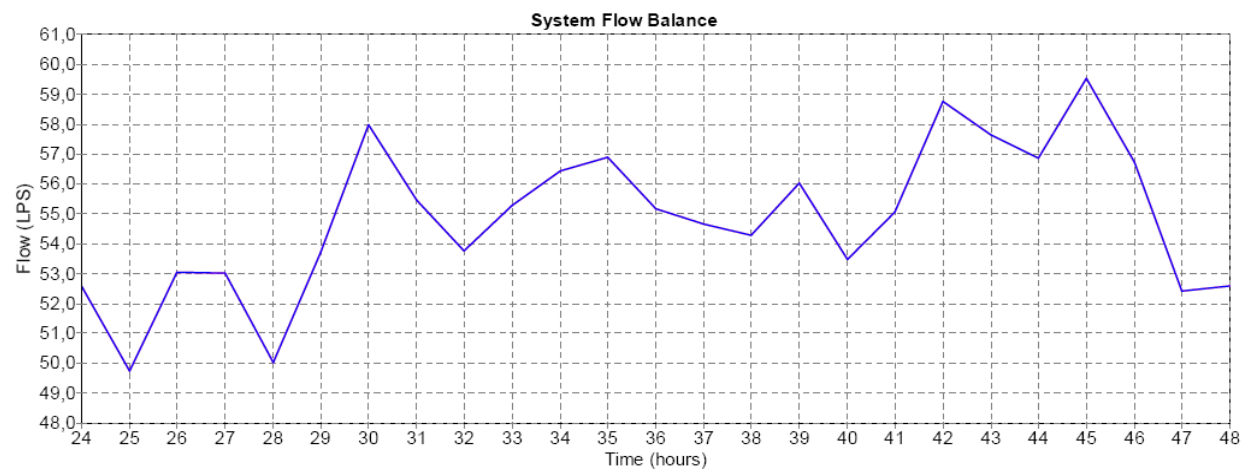

Fig. 6. Variability of total flow rate in the analysed water supply system

The results of calculations regarding the values of water pressure in the network nodes confirm that undisrupted operation during the entire time covered by the simulation is possible. An area revealing deviations from the remaining results is visible in one of the images. It is characterized by lower water pressure values as compared to the others, which results from the topography of the terrain, as had been mentioned in p. 2. Contour lines of water pressure at hours of highest and lowest water consumption have been presented in Figs. 7 and 8. 
The distribution of pressure in the characteristic nodes of the network supplying mining companies, industrial plants and residential households was also analysed. The results have been presented in Fig. 9.

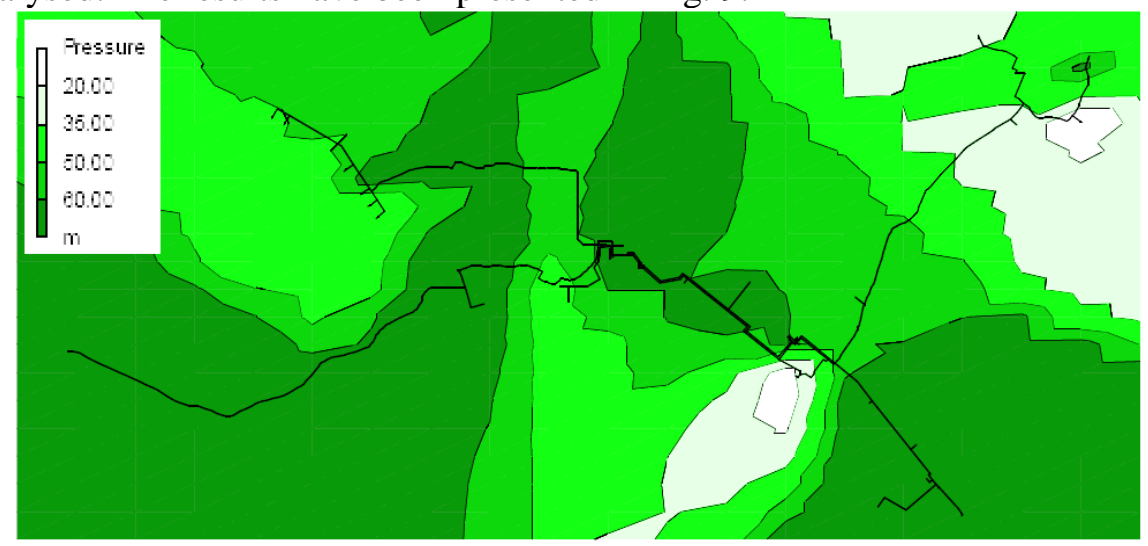

Fig. 7. Contour lines of water pressure in the network during minimal water demand

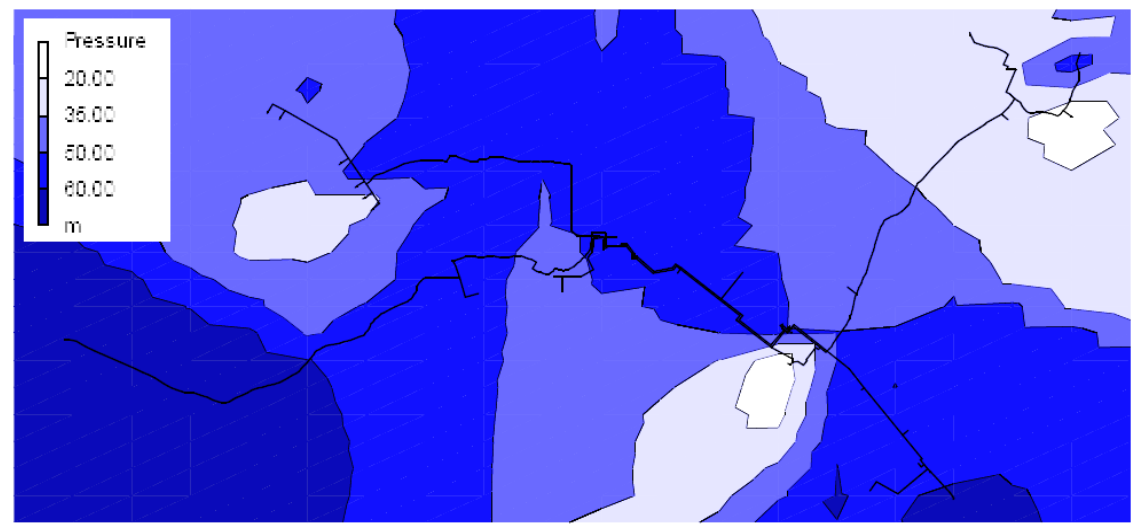

Fig. 8. Contour lines of water pressure in the network during maximal water demand

An unfavourable phenomena was observed in the area where residential housing is located. The highest values of pressure occur here, while the variability of pressure is significantly lower than in the case of mining companies and industrial plants. The permanent presence of excessive pressure is not favourable where potential water losses are concerned. This phenomenon may generate negative effects in the network of pipelines (especially in areas at risk of mining damage), and may also be a factor causing the fast wear and tear of seals in inside plumbing fixtures in the area of residential buildings. In time, efforts should be taken to realize a pressure management system in the network based on a control and monitoring system, for example using advanced pressure regulators or reducers. 


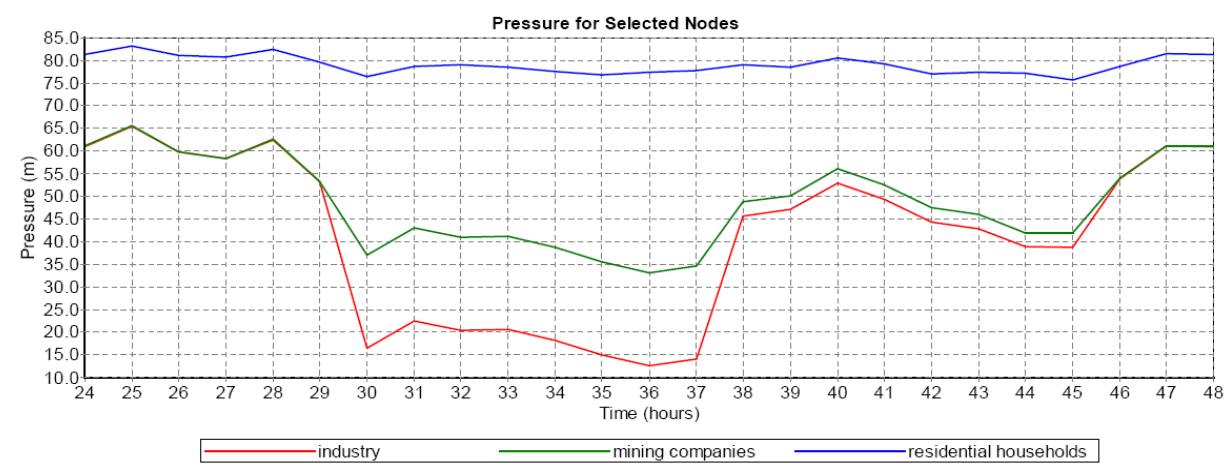

Fig. 9. Pressure variability in selected nodes of the network

\section{CONCLUSIONS}

The conducted analysis was aimed at assessing the hydraulic conditions in the water supply system supplying mining companies, industrial plants and individual households. The calculations carried out made it possible to determine the values of pressure for individual nodes as well as the flow rate and velocity for all sections of the network.

Based on the obtained results, the following conclusions were formulated:

- The analysed system is characterized by high variability of water consumers, which is reflected in the varied hourly water demand and flow parameters,

- variability of pressure in the analysed network is connected with the hourly pattern of demand for water,

- the highest values of pressure occur in the region where residential housing is located,

- for the residential area, the variability in pressure is significantly lower than for mining companies and industrial plants,

- industrial plants are characterized by the highest irregularity in water consumption and flow parameters,

- hours during which workers finish shifts and use showers have a significant influence on water consumption.

The results serve as confirmation of the methodology of preparing a balance of water demand in industrial plants, while the model of the water supply system may serve as the basis for further simulation calculations regarding the regulation of water pressure, means of supplying water, or water quality. It may also be a tool allowing for the influence of applying automatic systems of regulating operating conditions to be assessed and the preliminary selection of settings for regulating elements. 


\section{REFERENCES}

1. Mielcarzewicz E.: Gospodarka wodno - ściekowa $w$ zaktadach przemystowych, Warszawa, Państwowe Wydawnictwo Naukowe 1983.

2. Mielcarzewicz E.: Obliczenia systemów zaopatrzenia $w$ wodę, Warszawa, Arkady 2000.

3. Ogiołda E., Kozaczek M.: Charakterystyka zużcia wody w systemach wodociagowych „Wilków” $i$ „Borek” $w$ gminie Głogów, in: Zeszyty Naukowe Uniwersytetu Zielonogórskiego, seria: Inżynieria Środowiska nr 32 / 2013, 69-77.

4. Ogiołda E., Nowogoński I., Walas M.: Charakterystyka zużycia wody w Nowogrodzie Bobrzańskim, Rynek Instalacyjny, 11 (2015), 76-79.

5. Rossmann L.: EPANET 2, Users Manual. National Risk Management Research Laboratory Office of Research and Development U. S. Environmental Protection Agency, Cincinati 2000.

6. Wytyczne do programowania zapotrzebowania wody i ilości ścieków w miejskich jednostkach osadniczych. Instytut Gospodarki Przestrzennej i Komunalnej. Warszawa, 1991

\section{WPŁYW CZASOPRZESTRZENNEJ NIEJEDNORODNOŚCI WARUNKÓW POBORU WODY NA PARAMETRY SYSTEMU WODOCIĄGOWEGO}

$$
\text { Streszczenie }
$$

W pracy zaprezentowano wyniki analizy istniejącego systemu wodociągowego. Praca zawiera charakterystykę analizowanego terenu, na którym zlokalizowany został badany system, a także jego parametry dotyczące ujęć i transportu pompowego wody, długości oraz średnic rurociągów, wykonano również zestawienia materiałów, z których wykonana została sieć. Analizie poddano zapotrzebowanie na wodę z uwzględnieniem charakteru konsumentów korzystających z sieci. Uwzględniony został wpływ zmienności rozbiorów wody w ciągu doby dla podstawowych kategorii odbiorców. Do opracowania modelu systemu wykorzystano program do symulacji pracy sieci wodociągowych EPANET 2.0 opracowany i udostępniony przez U.S. Environmental Protection Agency na licencji public-domain. Uzyskane wyniki symulacji pozwoliły na wskazanie głównych problemów eksploatacyjnych analizowanego obiektu. Przeanalizowano rozkład ciśnienia w charakterystycznych węzłach sieci, z których zasilane są zakłady górnicze, przemysłowe i mieszkalnictwo. Wykazano przydatność opracowanego modelu symulacyjnego do przygotowania oceny przyszłych działań modernizacyjnych pozwalających ocenić skutki ich wdrożenia.

Słowa kluczowe: nierównomierność zużycia wody, parametry hydrauliczne sieci wodociągowej

Editor received the manuscript: 28.12.2016 